Historic, Archive Document

Do not assume content reflects current scientific knowledge, policies, or practices. 

1999.9
$F 76320$

Effects of Partial Cutting on Diseases,
Mortality, and Regeneration of Rocky
Mountain Aspen Stands

James W. Walters, Thomas E. Hinds, David W. Johnson, and Jerome Beatty

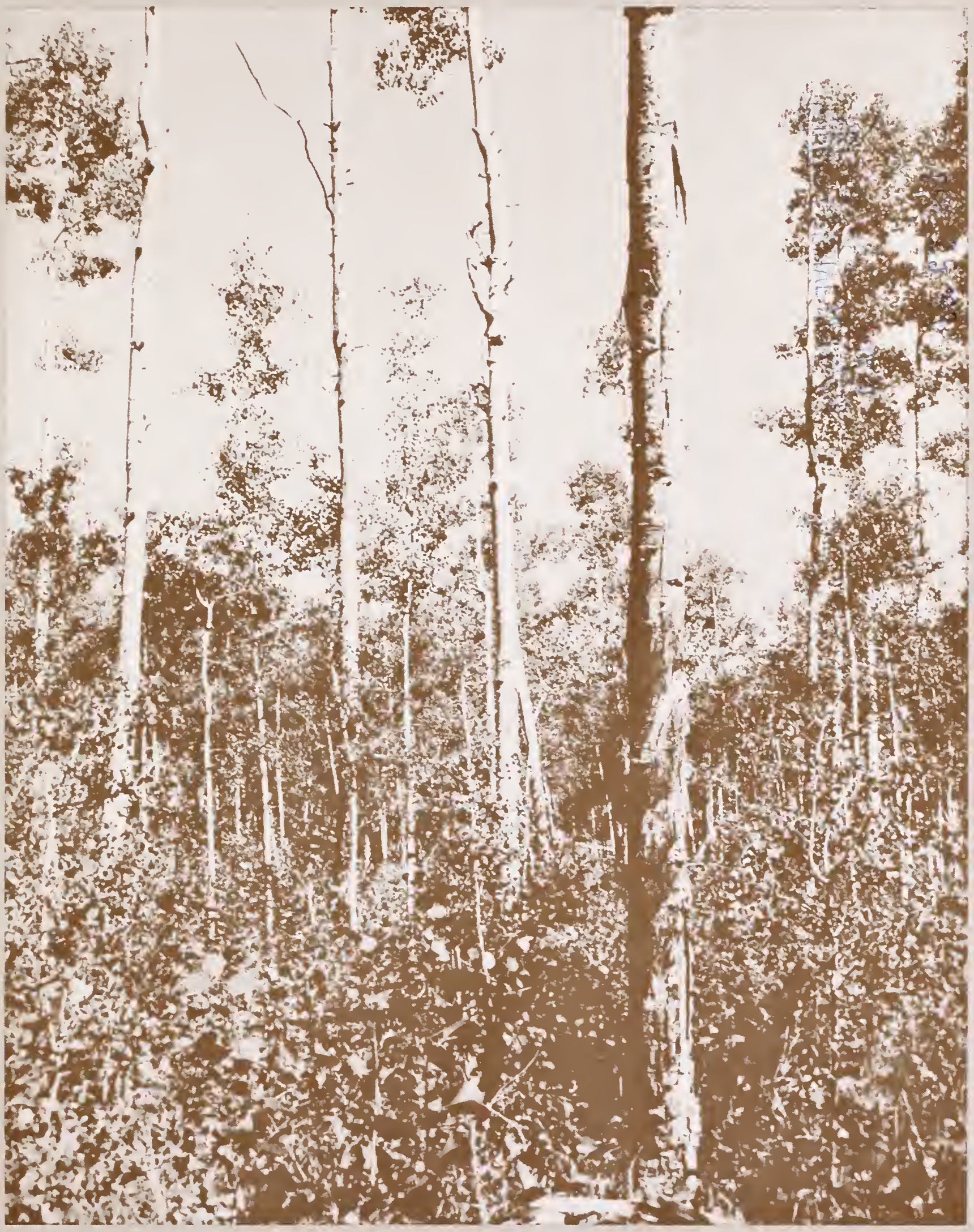

Research Paper RM-240

Rocky Mountain Forest and

Range Experiment Station

Forest Service

U.S. Department of Agriculture 


\title{
Effects of Partial Cutting on Diseases, Mortality, and Regeneration of Rocky Mountain Aspen Stands
}

\author{
James W. Walters, Plant Pathologist, Forest Pest Management, \\ State and Private Forestry, St. Paul, Minn.' \\ Thomas E. Hinds, Research Plant Pathologist, Rocky Mountain Forest \\ and Range Experiment Station, Fort Collins, Colo. ${ }^{2}$ \\ David W. Johnson, Supervisory Plant Pathologist, \\ Forest Pest Management, State and Private Forestry, Lakewood, Colo. \\ and \\ Jerome Beatty, Plant Pathologist, Forest Pest Management, \\ State and Private Forestry, Albuquerque, N. M.
}

\begin{abstract}
Logging wounds on residual aspen, in partially cut stands, predisposed wounded trees to attack by insects and diseases. Five to 7 years after cutting, aspen mortality amounted to $20 \% ; 41 \%$ of the live trees were infected with canker diseases; and $30 \%$ were infested with wood borers. Adequate sprouting occurred even though only $60-80 \%$ of the basal area was removed.
\end{abstract}




\title{
Effects of Partial Cutting on Diseases, Mortality, and Regeneration of Rocky Mountain Aspen Stands
}

\author{
James W. Walters, Thomas E. Hinds, David W. Johnson, and Jerome Beatty
}

\section{Management Implications}

Partial cutting in aspen, such as selection and shelterwood cutting, may have detrimental effects on the residual trees and may not be a desirable method of harvesting aspen stands. Tree wounds, common with usual logging practices, can become infected with canker diseases, which in this study killed $20 \%$ of the residual trees several years after logging. Additional infections remain on the trees causing continued mortality and making them more susceptible to wind breakage. Once a stand is opened by logging, increased sunscald and infestations by boring insects weaken residual trees. Removal of $60 \%$ to $80 \%$ of the basal area will still insure adequate sprouting to maintain the aspen type. However, the remaining overstory will eventually degenerate to the point of being worthless for timber harvest.

\section{Introduction}

Quaking aspen (Populus tremuloides Michx.) stands in the Rocky Mountain States occupy about 4.1 million acres of commercial forest land and contain an estimated 7.3 billion board feet of sawtimber (Green and Setzer 1974). Because many western aspen stands are mature or overmature, efforts to harvest them are increasing. Harvest methods include selection, shelterwood, group selection, and clearcutting of stands smaller than 40 acres. Because aspen have soft, living bark they are easily wounded, predisposing them to various insects and diseases. Residual trees often are wounded during selection and shelterwood cuts. The importance of logging wounds on aspen, and subsequent attack by various insects and diseases, has not been extensively studied in forest situations.

Wounds on aspen trees often provide entrance points for canker and trunk rot fungi. Ceratocystis canker, caused by Ceratocystis fimbriata Ell. \& Halst.; Cenangium canker, caused by Cenangium singulare (Rehm.) Davidson \& Cash, and Cryptosphaeria canker, caused by Cryptosphaeria populina (Pers.) Sacc. usually begin in wounds. These cankers, along with Cytospora canker, caused by Cytospora chrysosperma Pers. ex Fr., are the major causes of tree mortality in Rocky Mountain aspen stands (Juzwik et ai. 1978).

Heart rot is the primary cause of volume loss in aspen. Damage caused by heart rot results in cull of nonmerchantable stems. Hinds and Wengert (1977) found that decay losses in Colorado aspen were about $30 \%$ of the total gross board foot volume. Of the total cull volume, $66 \%$ was caused by trunk rots and $34 \%$ by butt rots. White trunk rot, caused by Phellinus tremulae Bond et Boris. (= Fomes igniarius), was the most frequently encountered decay. It was found in $15 \%$ of the 563 merchantable-sized trees in their study. Although trees are not directly killed by heart rot fungi, infected trees are frequently broken off during high winds.
The primary purpose of this continuing study is to determine the pathological effects of usual partial cutting practices in aspen stands. Other effects of partial cutting, including insect activity and sprout production, also were examined.

\section{Methods}

During 1974 and 1975, 11 plots were established in commercial aspen stands of northern New Mexico and southern Colorado. Plots were located in stands that had been partially cut within the previous three years. Cutting methods were those commonly used in commercial harvesting. The stands varied considerably in size; consequently the harvested plot size was varied to insure a representative sample of the area. Plots were square or rectangular and ranged in size from 0.6 to 1.2 acres. All trees 6 inches d.b.h. (diameter at breast height) or larger were examined in each plot. Trees were grouped in categories of live aspen, dead aspen, live conifer, or dead conifer. Each live aspen was numbered with paint for future identification.

A wide variety of site characteristics and stand conditions were represented by the plots (table 1). The original numbers of trees per acre and basal area prior to harvest was determined by adding the number of live and dead trees at the time of plot establishment to the number of stumps present on the plot and converting to a per acre basis. Basal area calculations were made by converting stump diameter to diameter at breast height using the relationship developed by Hann (1976).

In 1976, three uncut plots were established adjacent to the harvested plots as control plots for comparison of disease and mortality between cut and uncut stands. Because the control plots were near the extremity of the commercial stands, they were denser than the preharvest condition on the harvested plots, and contained, on the average, a larger basal area. Conse- 
Table 1.-Individual aspen plot data

\begin{tabular}{|c|c|c|c|c|c|c|c|c|}
\hline $\begin{array}{l}\text { National Forest } \\
\text { District } \\
\text { Plot Number }\end{array}$ & $\begin{array}{l}\text { Stand } \\
\text { cut }\end{array}$ & $\begin{array}{c}\text { Plot } \\
\text { established } \\
\end{array}$ & $\begin{array}{l}\text { Plot } \\
\text { size }\end{array}$ & Elevation & Aspect & Slope & $\begin{array}{c}\text { Site } \\
\text { index }\end{array}$ & $\begin{array}{c}\text { Average } \\
\text { age }\end{array}$ \\
\hline & - & ear- & --acres- & - feet - & & -percent-- & & - years- \\
\hline \multicolumn{9}{|c|}{ Carson National Forest } \\
\hline Plot 1 & 1973 & 1974 & 0.6 & 9,650 & east & 10 & 67 & 70 \\
\hline Plot 2 & 1973 & 1974 & 0.8 & 9,600 & east & 10 & 67 & 70 \\
\hline Plot 3 & 1974 & 1974 & 0.9 & 9,650 & west & 30 & 72 & 80 \\
\hline \multirow{2}{*}{\multicolumn{9}{|c|}{ Taos District }} \\
\hline & & & & & & & & \\
\hline Plot 4 & 1973 & 1975 & 1.2 & 9,400 & east & 30 & 70 & 175 \\
\hline Plot 5 & 1973 & 1975 & 0.6 & 9,200 & southwest & 20 & 50 & 98 \\
\hline \multicolumn{9}{|c|}{ San Juan National Forest } \\
\hline \multicolumn{9}{|l|}{ Pine District } \\
\hline Plot 6 & 1973 & 1975 & 1.0 & 9,600 & south & 3 & 70 & 72 \\
\hline Plot 7 & 1974 & 1975 & 0.8 & 9,400 & south & 4 & 80 & 84 \\
\hline Plot 8 & 1972 & 1975 & 0.8 & 9,000 & south & 3 & 78 & 68 \\
\hline Plot 9 & 1972 & 1975 & 1.0 & 9,200 & southwest & 6 & 68 & 68 \\
\hline Control Plot 2 & - & 1976 & 0.2 & 9,000 & south & 3 & 78 & 68 \\
\hline \multicolumn{9}{|c|}{ Rio Grande National Forest } \\
\hline \multicolumn{9}{|l|}{ Alamosa District } \\
\hline Plot 10 & 1974 & 1975 & 1.0 & 10,100 & southeast & 5 & 58 & 86 \\
\hline Plot 11 & 1973 & 1975 & 0.6 & 10,200 & southeast & 0 & 60 & 87 \\
\hline Control Plot 1 & - & 1976 & 0.2 & 10,200 & southeast & 0 & 60 & 60 \\
\hline
\end{tabular}

'Base age $=80$ years

quently, a 0.1 - or 0.2 -acre size plot was used to include a number of trees comparable to the number on harvested plots.

Plot data for live aspen trees included: tree number; diameter; crown class; height of old wounds; height, size, and cause of recent wounds; whether wounds penetrated the cambium; whether wounds were infected with a disease; height, size, and species of cankers; height and species of conks or other rot indicators; and presence of wood borers. Data recorded for dead aspen and live or dead conifers included tree species, diameter, and cause of death, when known. Only standing dead trees or recently windthrown trees were tallied. The presence and condition of bark on dead trees were used for indicators as to whether they had died since harvesting. Stump diameter was recorded for all cut trees. Site index measurements were taken on six trees at each plot location. Mean site index (base age $=80$ years) for each plot was calculated using the table developed by Jones (1966). Percent slope, aspect, elevation, and stand age were recorded for each plot.

A regeneration survey was made on each plot in 1977 and again in 1979 to determine the effect of basal area reduction on aspen sprout production. On harvested plots, the area was subdivided with a 1-chain grid. A milacre circular subplot (3.75-foot radius) was taken at the center of each 1-chain block (6-12 subplots per site). All trees on the milacre plot 6 inches d.b.h. or less were tallied. Similar subplots were established in the control plots, but a 0.5 -chain grid was used (4-8 subplots per site).

Trees on cutover plots were examined at the time of plot establishment and again in 1977 and in 1979. Data were collected on the control plots at the time of establishment and in 1979.

\section{Results and Discussion}

\section{Stand Conditions}

Prior to harvest, plots averaged 255 trees per acre and a basal area of 157 square feet. Conifer species including white fir, Abies concolor (Gord. \& Glend.) Lindl. ex Hildebr.; subalpine fir, A. lasiocarpa (Hook.) Nutt.; corkbark fir, A. lasiocarpa var. arizonica (Merr.) Lem.; Douglas-fir, Pseudotsuga menziesii (Mirb.) Franco; Engelmann spruce, Picea engelmannii Parry ex Engelm., and ponderosa pine, Pinus ponderosa Dougl. ex Laws comprised $10 \%$ of the live stems at harvest time and $14 \%$ of the residual stems. Because of the small numbers of conifers encountered in this study, and since this study dealt with aspen, conifers were not considered in the calculations except in the regeneration subplots (table 2). Control plots were denser (380 trees per acre) than preharvest plots and had a slightly higher basal area (183 square feet per acre). There were no conifers on the control plots.

Harvesting removed $58 \%$ of the aspen larger than 6.0 inches d.b.h., or $69 \%$ of the basal area per acre. Residual basal area for live trees ranged from 26 (figs. 1 and 2) to 88 (figs. 3 and 4), with an average of 48 square feet per acre. Mean basal area on harvested plots dropped from 157 square feet before harvest to 47 in 1979, while basal area on the control plots increased from 183 to 190 square feet.

At the time of plot establishment, 969 live and 179 dead aspen were tallied on harvested plots (table 3 ). Dead trees accounted for $16 \%$ of the residual aspen. By reconstructing the harvested plots to preharvest condition, it was estimated that $7 \%$ of all aspen were dead, based on their appearance, at the time of logging. Assuming that no dead aspen were harvested, the $7 \%$ 
Table 2.-Residual aspen basal area and regeneration on harvested and control plots

\begin{tabular}{|c|c|c|c|c|c|c|c|c|}
\hline \multirow{2}{*}{$\begin{array}{l}\text { Plot } \\
\text { Number }\end{array}$} & \multirow{2}{*}{$\begin{array}{l}\text { Residual } \\
\text { BA.1979 }\end{array}$} & \multicolumn{2}{|c|}{ Aspen-1977 } & \multicolumn{2}{|c|}{ Aspen-1979 } & \multicolumn{3}{|c|}{ Conifers-1979 } \\
\hline & & $<1$ inch d.b.h. & 1.6 inch d.b.h. & $<1$ inch d.b.h. & 1.6 inch d.b.h. & $<1$ inch & d.b.h. & 1.6 inch d.b.h. \\
\hline & $\mathrm{ft}^{2} / \mathrm{acre}$ & & & --trees/a & & & & \\
\hline 1 & 52 & $5,166 \pm 2,449$ & $166 \pm 200$ & $1,500 \pm 764$ & $167 \pm 167$ & 0 & & 0 \\
\hline 2 & 69 & $18,625 \pm 7,549$ & $375 \pm 375$ & $8,625 \pm 2,645$ & $750 \pm 412$ & 0 & & 0 \\
\hline 3 & 50 & $6,666 \pm 2,014$ & 0 & $5,222 \pm 1,899$ & 0 & $110 \pm$ & 111 & 0 \\
\hline 4 & 39 & $4,000 \pm 1,899$ & 0 & $3,583 \pm 1,422$ & $333 \pm 196$ & $333 \pm$ & 196 & 0 \\
\hline 5 & 85 & $500 \pm 342$ & 0 & $1,167 \pm 833$ & 0 & 0 & & 0 \\
\hline 6 & 39 & $11,500 \pm 2,367$ & 0 & $15,300 \pm 4,773$ & $100 \pm 100$ & $500 \pm$ & 342 & $100 \pm 100$ \\
\hline 7 & 45 & $6,625 \pm 1,821$ & $125 \pm 125$ & $7,000 \pm 2,061$ & $1,250 \pm 726$ & $1,125 \pm$ & 398 & $750 \pm 491$ \\
\hline 8 & 38 & $12,250 \pm 4,447$ & 0 & $13,625 \pm 3,664$ & 0 & $2,625 \pm$ & 1,700 & 0 \\
\hline 9 & 51 & $9,833 \pm 1,984$ & 0 & $9,166 \pm 1,598$ & 0 & $250 \pm$ & 130 & $250 \pm 130$ \\
\hline 10 & 34 & $47,900 \pm 9,367$ & 0 & $19,600 \pm 4,206$ & $300 \pm 153$ & 0 & & 0 \\
\hline 11 & 20 & $32,333 \pm 9,888$ & 0 & $18,000 \pm 3,022$ & 0 & 0 & & 0 \\
\hline Mean & 47 & $14,127 \pm 4,203$ & $60 \pm 36$ & $9,344 \pm 1,950$ & $264 \pm 121$ & $449 \pm$ & 241 & $100 \pm 69$ \\
\hline Control 1 & 209 & $3,333 \pm 1,022$ & 0 & $1,667 \pm 498$ & 0 & 0 & & 0 \\
\hline Control 2 & 185 & $167 \pm 167$ & 0 & 0 & 0 & $167 \pm$ & 167 & 0 \\
\hline Control 3 & 177 & $500 \pm 707$ & $250 \pm 354$ & $167 \pm 167$ & $167 \pm 167$ & 0 & & 0 \\
\hline Mean & 190 & $1,333 \pm 1,004$ & $83 \pm 83$ & $611 \pm 530$ & $56 \pm 56$ & $56 \pm$ & 56 & 0 \\
\hline
\end{tabular}

Table 3.-Aspen tree data for harvested and control plots in 1974-75 and 1979

\begin{tabular}{|c|c|c|c|c|c|c|c|c|c|}
\hline \multirow{2}{*}{$\begin{array}{c}\text { Plot } \\
\text { number }\end{array}$} & \multicolumn{6}{|c|}{ Year of plot establishment - 1974 or 1975} & \multicolumn{3}{|c|}{1979} \\
\hline & Total & Cut & Dead & Live & Ave. d.b.h. & Wounded & Dead & Live & Ave. d.b.h. \\
\hline & \multicolumn{4}{|c|}{-number trees- } & \multicolumn{2}{|c|}{-inches--- -percent-- } & \multicolumn{2}{|c|}{ number- } & -inches-- \\
\hline 1 & 141 & 68 & 4 & 69 & 9.7 & 69 & 15 & 54 & 10.2 \\
\hline 2 & 257 & 122 & 21 & 114 & 9.8 & 59 & 21 & 93 & 10.6 \\
\hline 3 & 205 & 80 & 37 & 88 & 9.1 & 72 & 5 & 83 & 9.7 \\
\hline 4 & 80 & 20 & 10 & 50 & 14.8 & 62 & 14 & 36 & 15.3 \\
\hline 5 & 159 & 64 & 16 & 79 & 11.0 & 89 & 5 & 74 & 11.3 \\
\hline 6 & 278 & 147 & 14 & 117 & 7.3 & 76 & 10 & 107 & 8.2 \\
\hline 7 & 204 & 98 & 18 & 88 & 8.3 & 73 & 8 & 80 & 9.1 \\
\hline 8 & 223 & 140 & 12 & 71 & 8.2 & 87 & 5 & 66 & 9.1 \\
\hline 9 & 410 & 234 & 31 & 145 & 7.6 & 86 & 6 & 139 & 8.1 \\
\hline 10 & 312 & 202 & 6 & 104 & 7.2 & 71 & 3 & 101 & 7.8 \\
\hline 11 & 223 & 169 & 10 & 44 & 8.0 & 98 & 15 & 29 & 8.6 \\
\hline Total & 2,492 & 1,344 & 179 & 969 & 9.2 & 77 & 107 & 862 & 9.8 \\
\hline Control & \multicolumn{6}{|c|}{ Year of plot establishment - 1976} & \multicolumn{3}{|c|}{1979} \\
\hline 1 & 77 & - & 2 & 75 & 9.7 & 27 & 1 & 74 & 9.9 \\
\hline 2 & 65 & - & 10 & 55 & 10.7 & 18 & 0 & 55 & 11.0 \\
\hline 3 & 52 & - & 3 & 49 & 8.0 & 33 & 1 & 48 & 8.1 \\
\hline Total & 194 & & 15 & 179 & 9.5 & 26 & 2 & 177 & 9.7 \\
\hline
\end{tabular}

mortality probably represented conditions in a natural stand before partial cutting. This closely coincides with the $8 \%$ mortality found in the control plots (fig. 4) which had 179 live and 15 dead trees at the time of establishment, and with the $9 \%$ mortality found in other natural aspen stands in Colorado (Hinds 1964).

\section{Incidence of Wounds, Diseases, and Insects}

The initial hypothesis was that partial cutting would result in numerous wounds on residual aspen, which would then increase the incidence of disease and subsequent tree mortality. At the time of plot establishment, $82 \%$ of the harvested plot trees sustained wounds: $5 \%$ with natural wounds, $14 \%$ with natural and logging wounds, and $63 \%$ with only logging wounds (table 3 ). Only $26 \%$ of the trees on control plots sustained wounds (i.e., excluding elk feeding wounds on aspen bark commonly referred to as elk barking), most of which were healed over. Wounds on control plot trees were caused by natural factors because the plots had not been logged. Elk barking was common on several plots. At the time of plot establishment, elk barking occurred on $16 \%$ of the trees in harvested plots and $53 \%$ of the control plot trees. One control plot had all of its trees barked by elk. During the period of observation, no elk barking wounds on any of the plots became visibly infected with a disease. In northwestern Wyoming, Krebill (1972) found that intensive elk barking increased aspen susceptibility to disease infection and subsequent mortality. In contrast, Hinds' (1964) study in Colorado showed no adverse effects from elk barking or rodent feeding. The reason for this disparity is unknown. 



Figure 1. - Plot 11 had the lowest residual basal area of 26 square feet per acre (A), and six years after harvest there were 18,000 spouts per acre (B). 

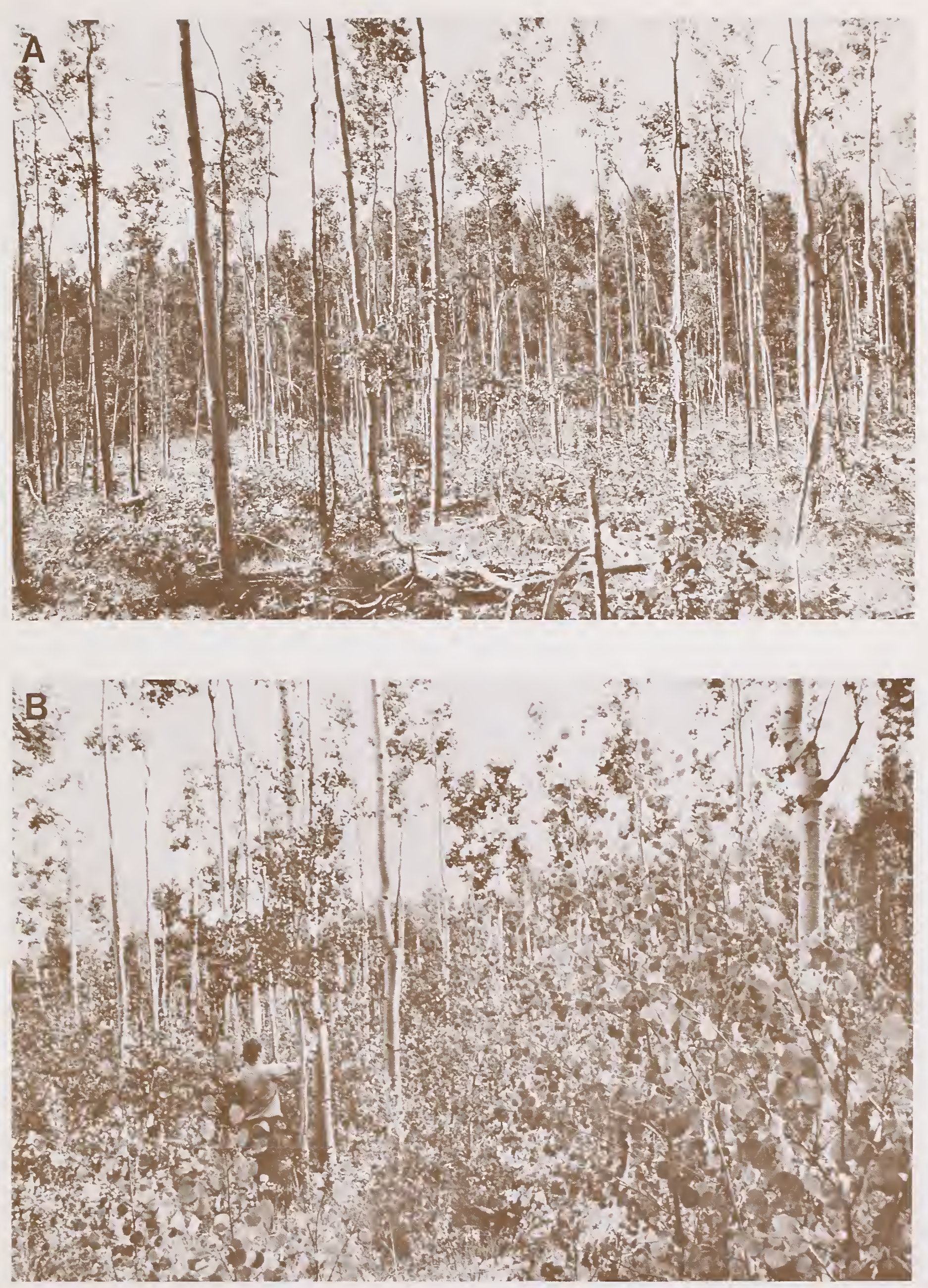

Figure 2. A low residual basal area of 30 square feet per acre on plot 10 (A) resulted in 19,600 sprouts per acre five years after harvest (B). 

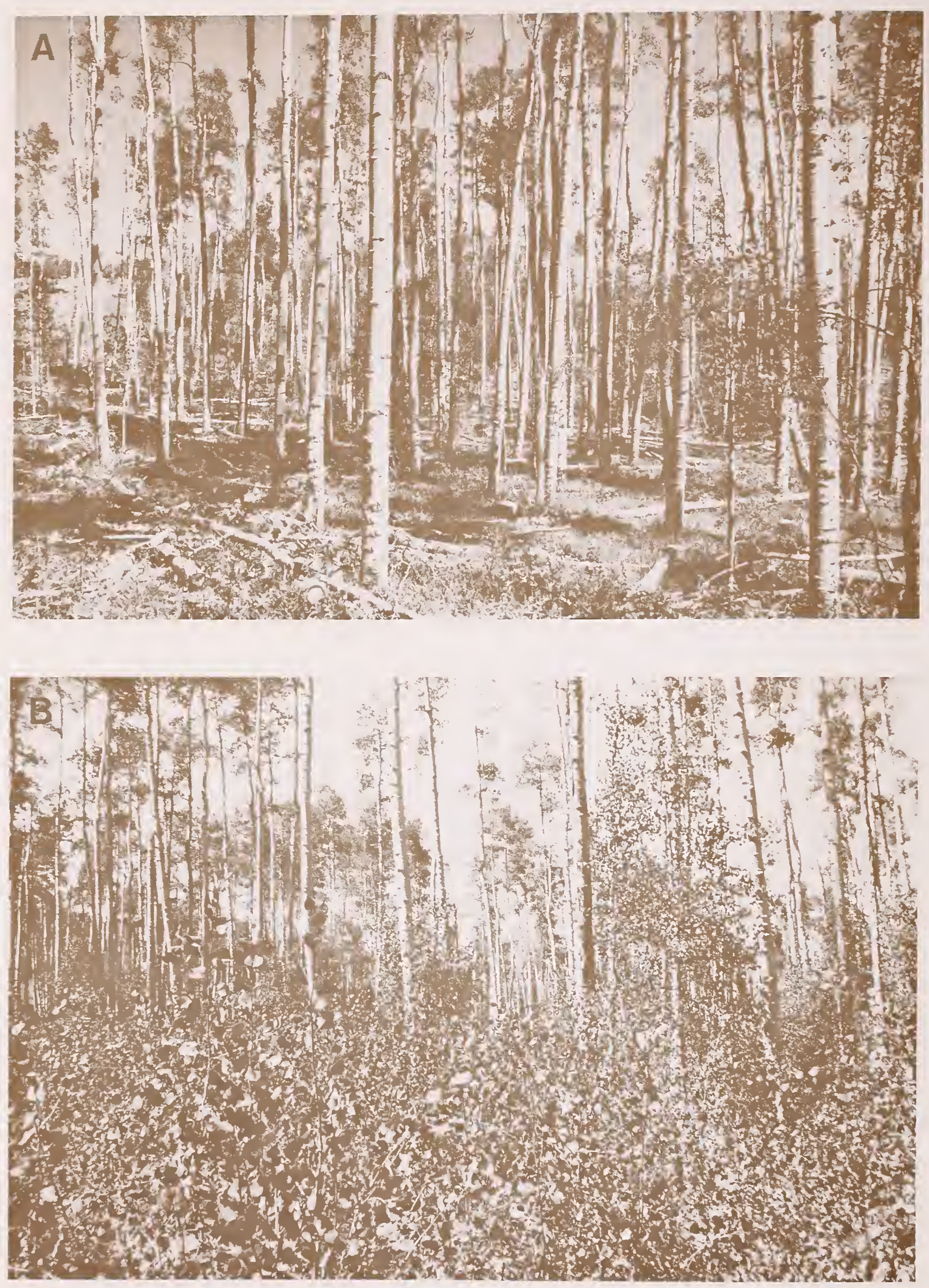

Figure 3. - Even with a high residual basal area of 76 square feet per acre (A), plot 2 had 18,600 sprouts per acre four years after harvest (B). 

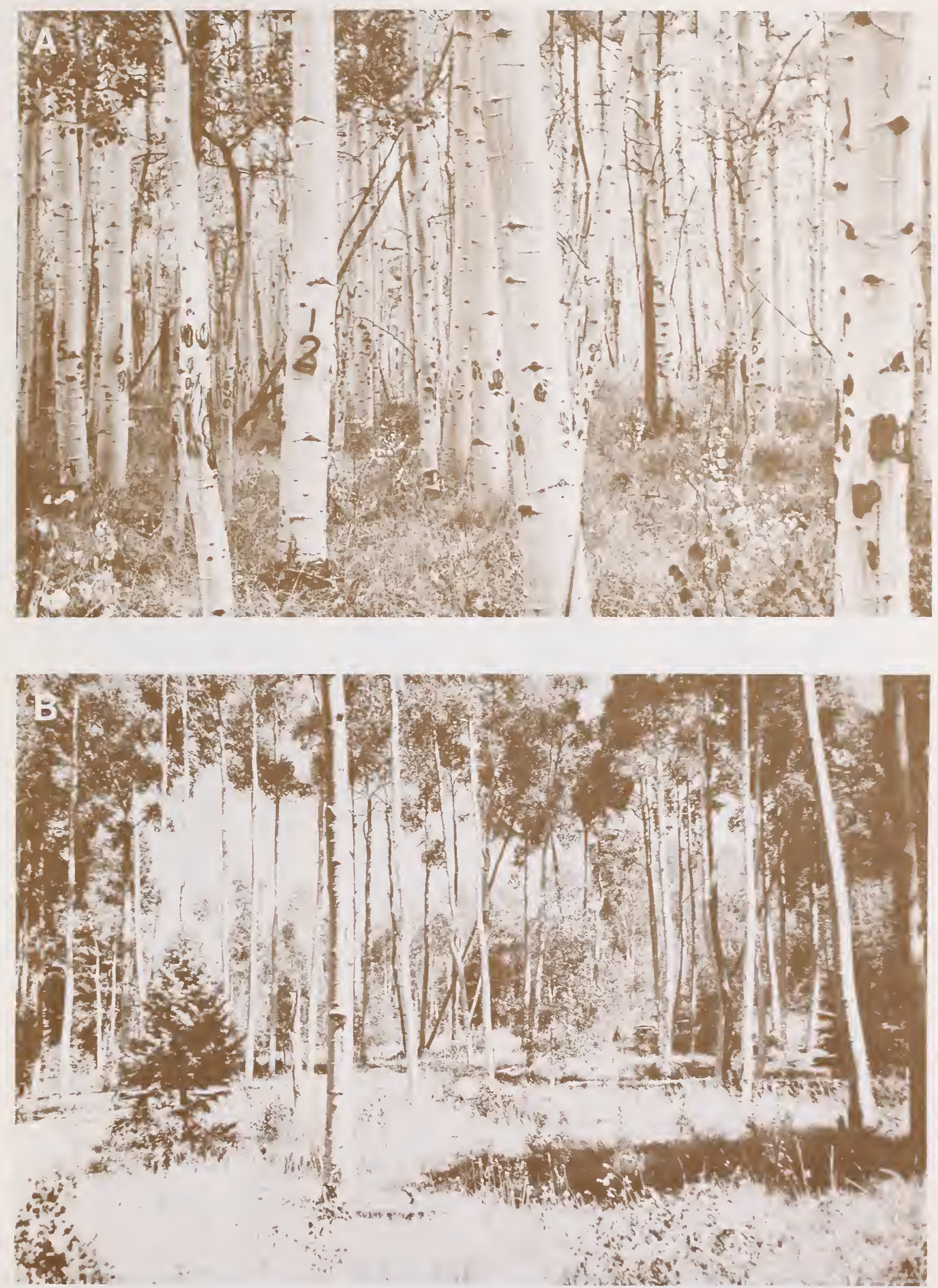

Figure 4.-Stand conditions in control plot 1 were similar to those in harvested plots prior to harvest (A). Plot 5 had a high residual basal area ( 88 square feet per acre) and sprouts had been heavily grazed upon by cattle. Only 1,200 sprouts per acre were present six years after harvest (B). 
In $1979,89 \%$ of the 969 live residual trees on harvested plots were still living. The proportion of trees with visible cankers on these plots increased from $9 \%$ in $1974-75$ to $45 \%$, including canker caused mortality, by 1979. Live tree infection on the harvested plots by canker type in 1979 was: Ceratocystis (fig. 5A) $33 \%$, Cenangium (fig. 5B) 4\%, Cryptosphaeria (fig. 5C) $1 \%$, Cytospora $2 \%$, and unidentified cankers $6 \%$. Trees often had more than one type of canker and some cankers could not be identified. Cankers were present on $7 \%$ of the live trees on control plots at the time of establishment and increased to $8 \%$ by 1979 ; all were Ceratocystis.

The association between natural or mechanical injuries to aspen bark and increased disease incidence has been previously documented. In a study of aspen mortality in Rocky Mountain campgrounds, Hinds (1976) found the incidence of cankers on live trees with numerous mechanical injuries to be: Ceratocystis-29\%, Cytospora-10\%, Cenangium-5\%, and Cryptosphaeria-1\%. In contrast, a recent survey (Juzwik et al. 1978) of natural aspen stands on nine National Forests in Colorado revealed the occurrence of cankers on live aspen to be: Ceratocystis-4.4\%, Cenangium$1.1 \%$, and Cryptosphaeria-1.1\%. Canker incidence on the control plots in the present study was: Ceratocystis-8\%, with no infections by Cenangium, Cryptosphaeria, or Cytospora.

White trunk rot, caused by the false tinder fungus, $P$. tremulae, was the primary rot found in the residual aspen. At the time of plot establishment, $7 \%$ of the residual trees on harvested plots had external signs (i.e., conks) of this fungus (fig. 6A) and fewer than $1 \%$ had other rots. By 1979, 11\% of the trees had visible signs of white trunk rot and $4 \%$ were infected with other rot organisms. Three percent of the aspen on control plots were infected with white trunk rot in 1976, and none exhibited signs of any other rot. By 1979, 4\% showed signs of white trunk rot, and $1 \%$ were infected with other rot organisms. In injured campground aspen, Hinds (1976) found white trunk rot conks on $6 \%$ of the trees. In western Colorado aspen stands, Hinds and Wengert (1977) encountered white trunk rot in $15 \%$ of the trees sampled, but conks were present only on $75 \%$ of the infected trees (i.e., $25 \%$ of the infected trees had no external signs of this fungus). In natural
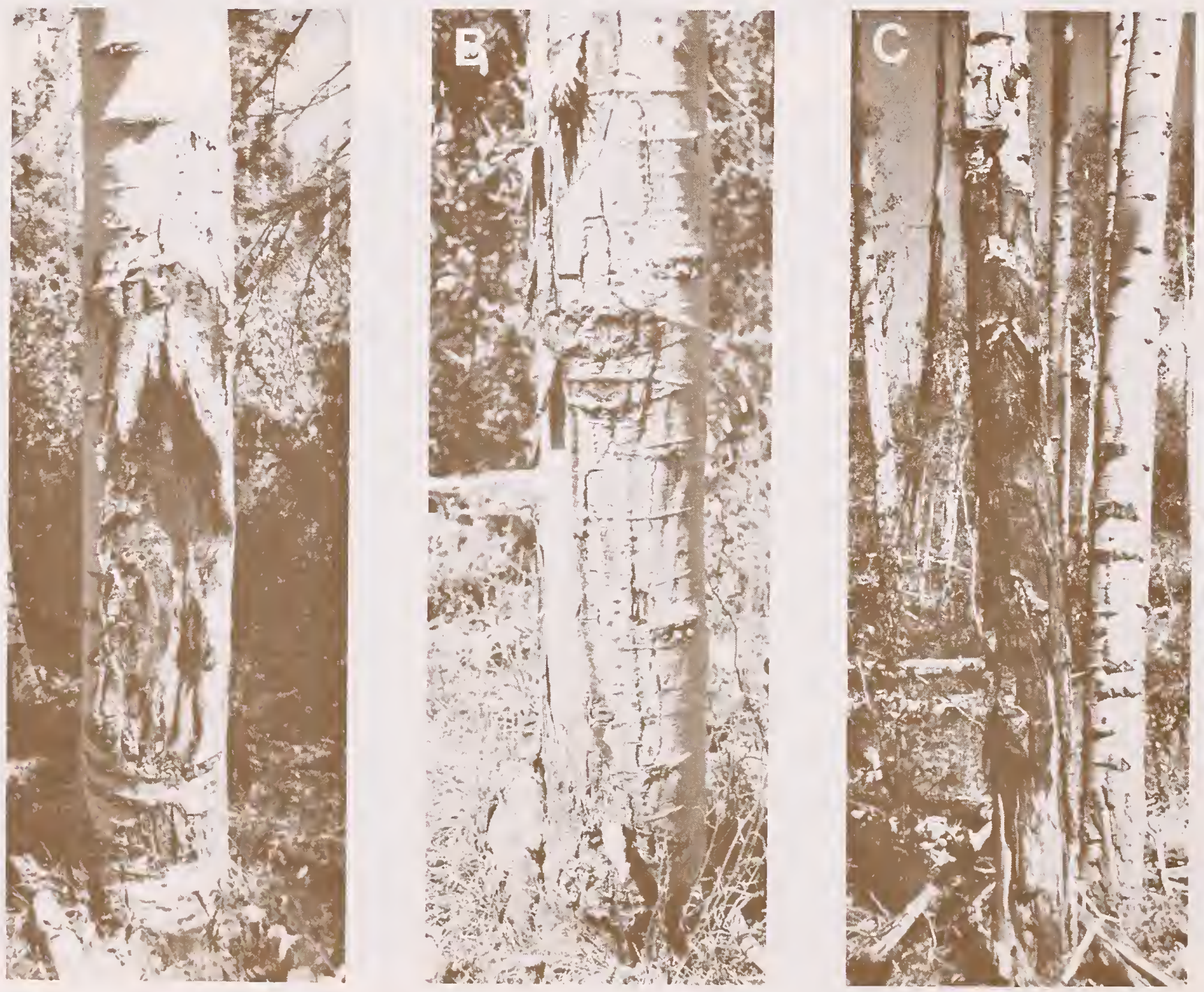

Figure 5.-Ceratocystis canker (A) was the most common disease found during the study, but Cryptosphaeria canker $(B)$ and Cenangium canker $(C)$ were the most important cankers causing tree mortality. 
stands, Juzwik et al. (1978) found white trunk rot conks on $4 \%$ of the live aspen; however, Hinds (1964, unpublished data) found the conks on $6 \%$ of the live aspen examined.

Long-term studies are needed to determine any relationships between rot incidence and wounds. Although the percentage of trees showing signs or symptoms of rot increased on the harvested and control plots during the relatively short time period of the observations in this study, the slow development of conks precludes the establishment of any definite relationship, at this time, between wounding and trunk rot incidence. In addition, trees with conks on them probably would not have been cut during harvesting; thus, the percent of residual trees may have been artificially increased.

Sunscald often injures smooth-barked trees that are suddenly exposed to direct sunlight. Injury often follows in stands opened by harvesting or thinning operations, and is most frequent on the south or southwest sides of affected trees. Although areas of bark can be killed, trees seldom die from this injury alone. However, sunscald injuries often provide entry points for disease organisms.

The incidence of sunscald on live aspen in this study fluctuated during the period of observation. Initially, no residual trees on harvested plots were affected, but by 1977 , about $7 \%$ (63 trees) of the living trees had been injured. Most injury occurred in plots 10 and 11 on the Rio Grande National Forest, Colorado. These plots had been heavily cut and retained the lowest residual basal areas of the 11 plots sampled. Both plots had a southeast aspect.

By 1979, many of the sunscald injuries had become infected with canker-causing fungi. Cankers that developed directly from sunscald wounds included 21 Ceratocystis cankers, six Cenangium cankers, three Cryptosphaeria cankers, and two Cytospora cankers. In addition, two trees were killed by sunscald alone. Five trees on plot 11 were cut between 1977 and 1979, but four of the five had severe sunscald in 1977 and probably died as a result of the injury. The trees were no doubt dead and cut as deadwood for firewood purpose. Of the remaining 24 trees (from the 63 affected in 1977), 19 had healed over and five still had sunscald damage in 1979. Although sunscald alone did not result in significant mortality, it predisposed half of the affected trees to infection by canker-causing fungi.

The occurrence of wood boring insects infesting aspen has been well documented (Hinds 1964, 1976; Hofer 1920; Juzwik et al. 1978; Krebill 1972), although
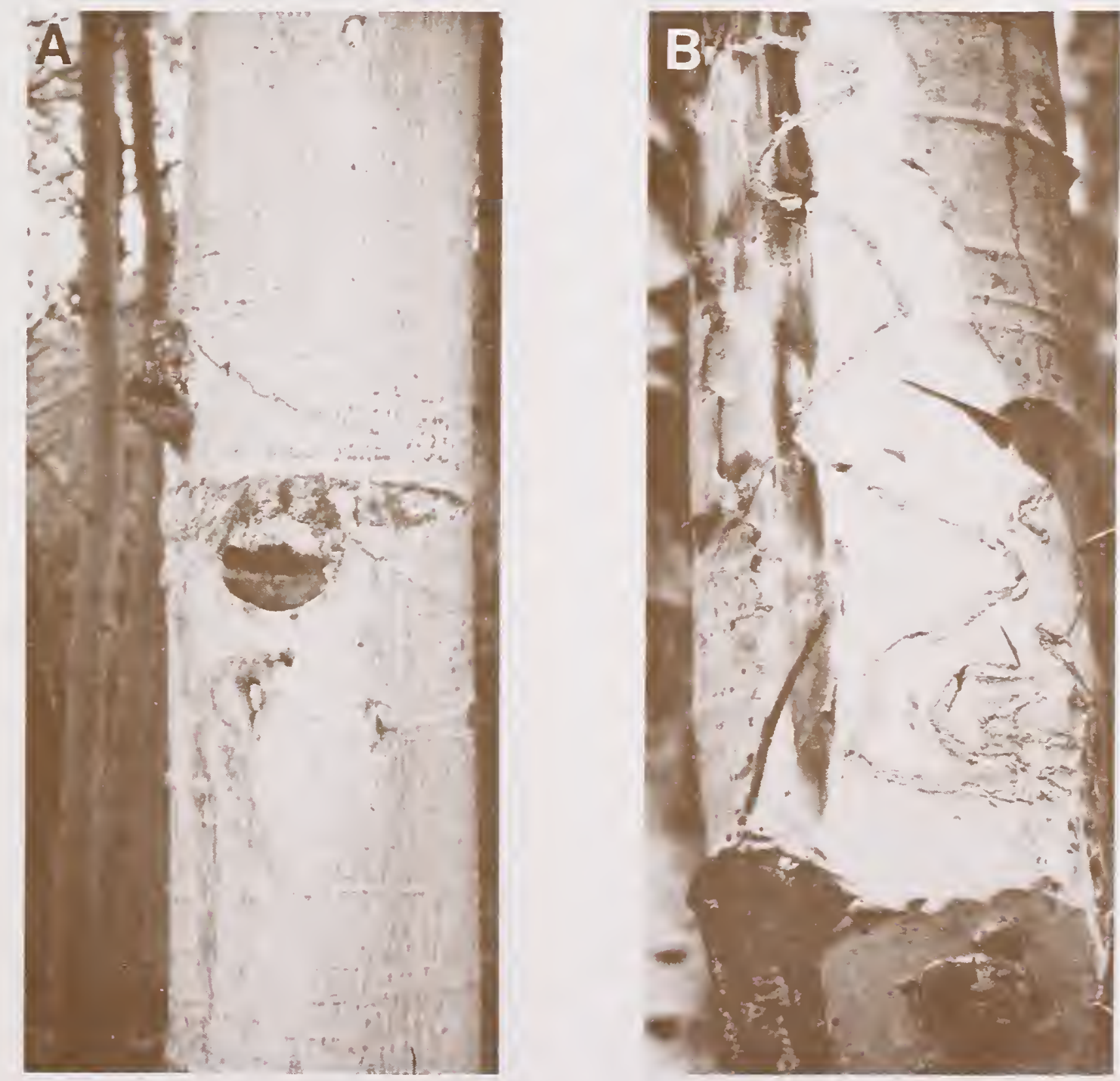

Figure 6.-Conks produced by the false tinder fungus $P$. tremulae, $(A)$, were present on $11 \%$ of the trees in 1979. Removal of the outer bark on borer.infested trees revealed winding galleries (B), probably caused by the bronze poplar borer. 
only one survey (Boss 1972) contained data on the insect species involved. Boss surveyed aspen insects in Colorado and found the bronze poplar borer, Agrilus liragus Barter and Brown, to be associated with natural and mechanically wounded aspen. Although no insects were collected in this evaluation, gallery patterns were similar to those caused by the bronze poplar borer (fig. 6B). Previous studies (Hinds 1964, Krebill 1972) indicated that borer attacks cause wounds in living aspen bark and predispose injured trees to other insects and diseases. The amount of tree mortality associated with borer attacks is unknown but assumed to vary with the insect species involved.

Previous surveys in Colorado indicated that the incidence of borers was about $2 \%$ or $3 \%$ in living trees in natural stands, and $18 \%$ in mechanically injured aspen (Hinds 1976). Eleven percent of the residual trees in harvested plots at the time of plot establishment were infested with borers. By 1977, the proportion increased to $13 \%$ and, in $1979,30 \%$ of the live aspen were infested with borers. The infestation levels for control plots were $4 \%, 2 \%$, and $12 \%$ in 1976,1977 , and 1979 respectively.

The cause of the substantial increase in the 1979 borer populations was not determined but it may be related to stand opening. The increase in attacks on control plots may be a result of borers spreading from the harvested areas into adjacent uncut areas. However, because no insect species were identified in this study, the overall importance of borer attacks could not be determined at this time.

\section{Aspen Mortality}

The major cause of tree mortality present on both harvested and control plots at the time of establishment was Cenangium canker. Mortality factors and the percentage of trees killed at that time were:

\begin{tabular}{lrlr}
\multicolumn{2}{c}{ Harvested plots } & \multicolumn{2}{c}{ Control plots } \\
Cenangium canker & $47 \%$ & Unknown & $53 \%$ \\
Logging damage & $27 \%$ & Cenangium canker & $40 \%$ \\
Unknown & $17 \%$ & Butt rot* & $7 \%$ \\
Windthrow & $7 \%$ & & \\
Cryptosphaeria canker & $2 \%$ & & \\
*Ganoderma applanatum & (Pers. ex Walls.) Pat. (= Fomes ap- \\
planatus) & & &
\end{tabular}

Residual aspen mortality varied from $3 \%$ to $34 \%$ of the trees per plot since plot establishment. Nine percent of all residual trees died between logging and plot establishment. An additional $11 \%$ of the residuals died between plot establishment and 1979. Thus, total tree mortality since logging was $20 \%$ of the residual live trees. Tree mortality on control plots between 1976 and 1979 was insignificant (1\%). The difference between tree mortality on control plots and harvested plots corroborates the adverse effect of partial cutting in overall deterioration of the residual stand.
Tree mortality causes and their distribution among harvested plots since plot establishment were as follows:

$\begin{array}{lrr}\text { Mortality factor } & \begin{array}{c}\text { Percent of } \\ \text { mortality }\end{array} & \begin{array}{r}\text { Percent } \\ \text { of plots }\end{array} \\ \text { Canker: } & 48 & 100 \\ \quad \text { Cenangium } & 7 & 36 \\ \text { Cryptosphaeria } & 1 & 9 \\ \text { Ceratocystis } & 1 & 9 \\ \quad \text { Cytospora } & 6 & 36 \\ \text { Windthrow } & & \\ \text { Wind breakage resulting from } & & 27 \\ \quad \text { Cenangium canker } & 11 & 18 \\ \text { Ceratocystis canker } & 9 & 55 \\ \quad \text { Trunk rot } & 3 & 18 \\ \text { Sunscald } & 2 & 9 \\ \text { Logging damage } & 6 & 18 \\ \text { Other } & & \end{array}$

Ceratocystis canker alone was not a major cause of tree mortality (1\%), but it predisposed some trees to wind breakage ( $11 \%$ of mortality). Wind breakage at Cenangium cankers was responsible for $7 \%$ of the tree mortality; however, the virulent nature of Cenangium canker probably negates the importance of wind as a contributing mortality factor. Wind, combined with trunk, butt, or root rots, was associated with $15 \%$ of tree mortality and may become more important in the future.

Canker-caused tree mortality will likewise add to future tree loss. Those trees with Cenangium and Cryptosphaeria canker will probably die within a few years, whereas the future of those with Cytospora and undetermined cankers are questionable at this time. In addition, the large number of residuals with Ceratocystis canker, in combination with wind breakage, may also add to future tree loss.

\section{Regeneration Following Partial Cutting}

Regeneration was sampled in 1977 and 1979. The mean number of sprouts smaller than 1 inch d.b.h. per acre decreased on harvested plots from 14,127 土 4,203 in 1977 to $9,344 \pm 1,950$ in 1979 (table 3). The number of sprouts decreased on seven plots and increased on four. Sprouting was sparse to absent on the control plots. In most cases, the more trees harvested and/or the lower the residual basal area, the more sprouts that developed in the plot (figs. 1B, 2B, 3B). This result coincides with previous work (Schier and Smith 1979, Stoeckeler and Macon 1956), where number of sprouts increased with number of stems and basal area removed. Several harvested plots had some residual aspen trees in the 1- to 6-inch d.b.h. category, but these did not appear to affect sprout numbers. Conifers smaller than 6.1 inches d.b.h. were found on 6 of the 11 plots. By 1979, they represented 6\% of the total regeneration, which was essentially the same proportion as before cutting. 
Other studies (Baker 1925, Graham et al. 1963) have indicated that although partial cutting may maintain the aspen type, adequate sprouting requires nearly complete removal of the overstory. Most harvested plots had from $60 \%$ to $80 \%$ of the basal area removed during cutting. In a study of aspen regeneration on an Arizona clearcut, Jones (1975) found about 14,000 sprouts per acre the year after harvest. After four growing seasons, about 10,700 sprouts per acre remained on the clearcut. Other studies (Graham et al. 1963) indicated that a minimum of about 6,000 sprouts per acre were needed for adequate regeneration.

The mean number of sprouts per acre on harvested plots was similar to that reported by Jones (1975) even though these stands were partially cut. Most plots had the recommended minimum of about 6,000 sprouts per acre after harvest. By 1979, plots 1, 4, and 5 had substantially fewer sprouts than the remaining harvested plots. The decrease in live sprouts per acre on plot 1 was probably due to heavy cattle grazing following harvesting. The relatively low number of sprouts originating on plot 4 was probably a result of the advanced age of the parent stand. Aging aspen stands reportedly decrease in sprouting capacity (Maini 1972). Plot 5 (fig. 4B) had the highest residual basal area with only $41 \%$ of the preharvest basal area having been removed. Apparently, insufficient overstory removal resulted in a lack of root sprout stimulation.

The mortality rate for sprouts in plots 10 and 11 was typical for relatively high density suckering (Jones 1975). Competition and shading usually reduce sprout density to a level commensurate with site capability.

\section{Summary}

Each of the harvest methods used in Rocky Mountain aspen stands has its advantages and disadvantages. The purpose of this study was to determine the consequences of partial cutting in aspen stands. Our results suggest that partial cutting has several detrimental effects on residual aspen and may not be a desirable method of harvesting aspen stands.

Although there were differences between harvested and control plots in plot size and tree density, the increase in diseases and mortality is so great in the harvested plots that the question of comparability does not adversely affect the inferences obtained from the data. Sprouting was variable among subplots, which resulted in substantial standard errors; however, sufficient regeneration will be produced to maintain the stands as aspen.

Wounds on the living bark of aspen frequently predisposed affected trees to attack by insects and disease. Logging wounds often served as entry courts for canker-causing fungi. Partial cutting also exposed residual trees to increased sunlight and, in some cases, resulted in sunscald injuries. About half of the sunscald injuries became infected with canker diseases. In contrast, elk barking had no effect on insect or disease incidence.
In the 5-7 year period since logging, $45 \%$ of residuals alive after logging were infected with cankers and aspen mortality averaged $20 \%$. This mortality rate was nearly three times that calculated for the plots before harvest, and 20 times the rate in control plots. The most important cause of tree mortality was Cenangium canker, followed by Ceratocystis canker in combination with wind. Cenangium cankers caused nearly half the tree mortality that occurred during the study. However, the current high incidence of Ceratocystis canker $(33 \%)$ on residual trees may be of greater significance in the future.

Although land managers must consider many factors in determining the best method of harvesting a stand, results of this study indicate that the pathological problems associated with partial cutting aspen should be carefully considered.

\section{Literature Cited}

Baker, Frederick S. 1925. Aspen in the central Rocky Mountain region. USDA Bulletin 1291, 46 p. Washington, D.C.

Boss, Gary D. 1972. Insects affecting quaking aspen in Colorado. 123 p. Master's thesis, Colorado State University, Fort Collins.

Graham, Samuel A., Robert P. Harrison, Jr., and Casey E. Westell, Jr. 1963. Aspens: Phoenix trees of the Great Lakes Region. 272 p. University of Michigan Press, Ann Arbor.

Green, Alan W., and Theodore S. Setzer. 1974. The Rocky Mountain timber situation, 1970. USDA Forest Service, Resource Bulletin INT-10, 78 p. Intermountain Forest and Range Experiment Station, Ogden, Utah.

Hann, David W. 1976. Relationship of stump diameter to diameter at breast height for seven tree species in Arizona and New Mexico. USDA Forest Service Research Note INT-212, 16 p. Intermountain Forest and Range Experiment Station, Ogden, Utah.

Hinds, Thomas E. 1964. Distribution of aspen cankers in Colorado. Plant Disease Reporter 48:610-614.

Hinds, Thomas E. 1976. Aspen mortality in Rocky Mountain campgrounds. USDA Forest Service Research Paper RM-164, 20 p. Rocky Mountain Forest and Range Experiment Station, Fort Collins, Colo.

Hinds, Thomas E., and Eugene M. Wengert. 1977. Growth and decay losses in Colorado aspen. USDA Forest Service Research Paper RM-193, 10 p. Rocky Mountain Forest and Range Experiment Station, Fort Collins, Colo.

Hofer, George. 1920. The aspen borer and how to control it. USA Farmer's Bulletin 1154, 12 p. Washington, D. C.

Jones, John R. 1966. A site index table for aspen in the southern and central Rocky Mountains. USDA Forest Service Research Note RM-68, 2 p. Rocky Mountain Forest and Range Experiment Station, Fort Collins, Colo. 
Jones, John R. 1975. Regeneration on an aspen clearcut in Arizona. USDA Forest Service Research Note RM-25, 8 p. Rocky Mountain Forest and Range Experiment Station, Fort Collins, Colo.

Juzwik, Jennifer, Wayne T. Nishijima, and Thomas E. Hinds. 1978. Survey of aspen cankers in Colorado. Plant Disease Reporter 62:906-910.

Krebill, Richard G. 1972. Mortaility of aspen on the Gros Ventre elk winter range. USDA Forest Service Research Paper INT-129, 16 p. Intermountain Forest and Range Experiment Station, Ogden, Utah.
Maini, J. S. 1972. Silvics and ecology in Canada. p. 67-73. In Aspen: Symposium proceedings. USDA Forest Service General Technical Report NC-1, 154 p. North Central Forest Experiment Station, St. Paul, Minn.

Schier, George A., and Arthur D. Smith. 1979. Sucker regeneration in a Utah aspen clone after clearcutting, partial cutting, scarification, and girdling. USDA Forest Service Research Note INT-253, 6 p. Intermountain Forest and Range Experiment Station, Ogden, Utah.

Stoeckeler, J. H., and John W. Macon. 1956. Regeneration of aspen cutover areas in northern Wisconsin. Journal Forestry 54:13-16.

\section{Acknowledgements}

The authors express their appreciation to Robert L. James and Thomas D. Landis, formerly Forest Pest Management, State and Private Forestry, Lakewood, Colorado, for their assistance in plot establishment or data recording during the course of this study. Appreciation is also expressed to Forest Service personnel on the Carson, Rio Grande, and San Juan National Forests for their assistance in study plot locations. 


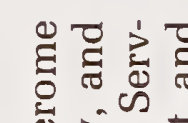

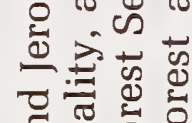

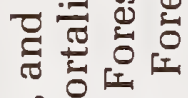

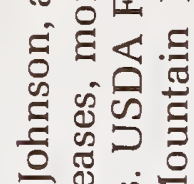

을

3 उ

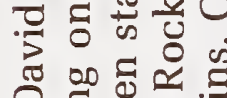

品 뭉

क

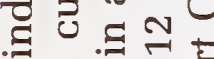

现

wi

品运定

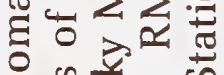

은 흔

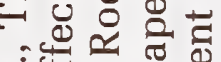

उ舟响 은

\&

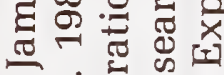

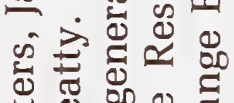

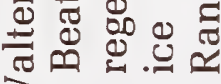

3

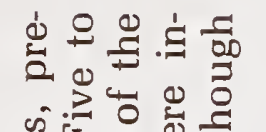

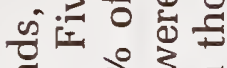

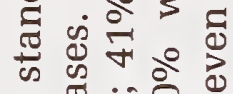

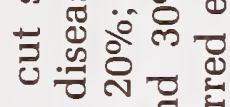

뭉으 뜨

ฮี

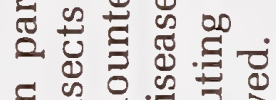

$\subseteq$.

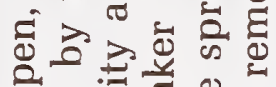

क्ष

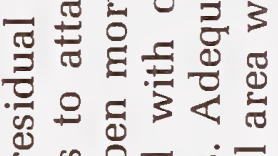

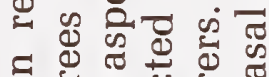

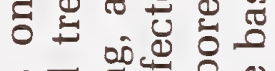

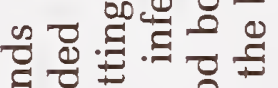

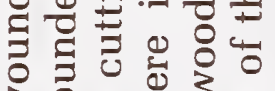

3 先3

Do

00

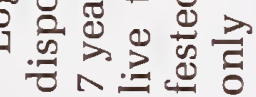

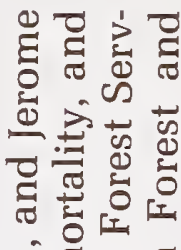

ฮี่

ฏึّ

등요워

了용 등 츙 i o : 0

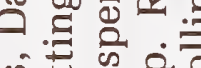

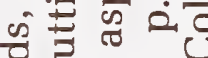
U U 疍营 돓워

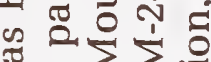
㟧 $\sum_{0}$

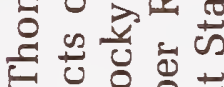
—

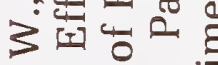

ఖ ฮี่

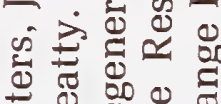
䒕

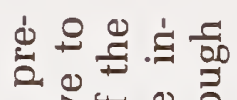

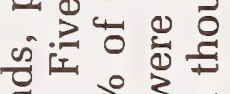
कृ

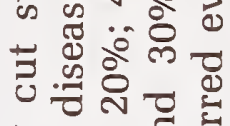
츠은

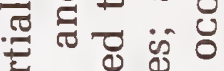

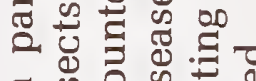
. ब류

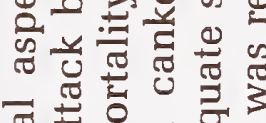

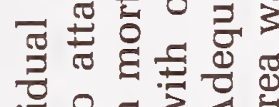

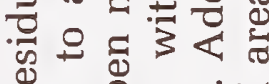

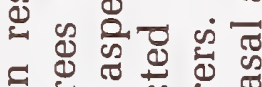
¿ป

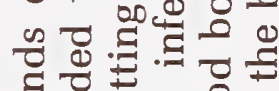

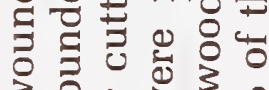

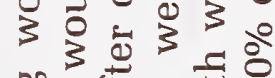

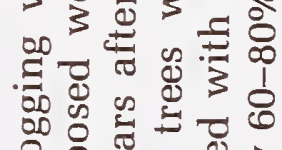

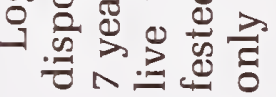

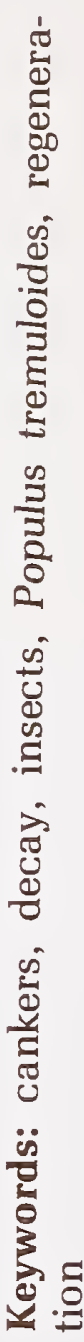

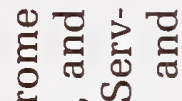

$\stackrel{0}{=} \overline{0}$

글

ฮิ

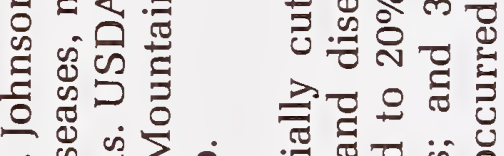
की 广象递 등 - कि की ฮี क क ป 可 즐

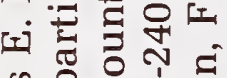
m $2 \sum \sum^{1}$ हี่

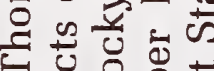

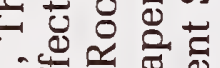
उ四范 ฆ ฮู

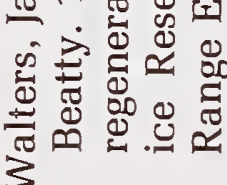

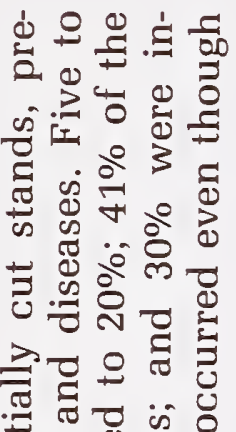

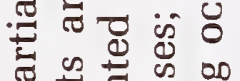

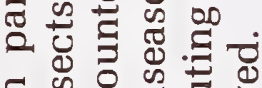

ఏ

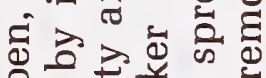

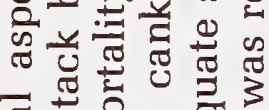

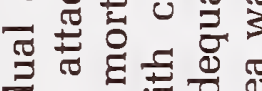

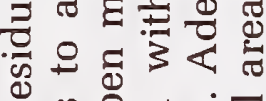

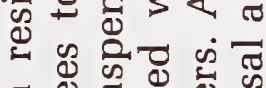
ฐ

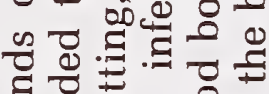

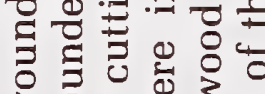

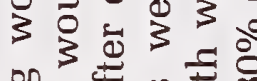
0. .0. 0.

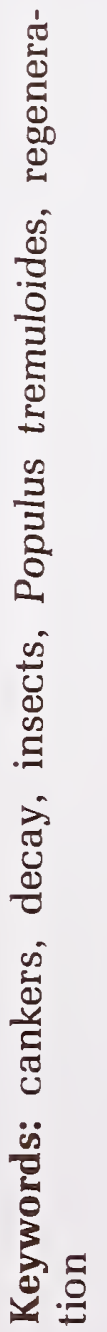

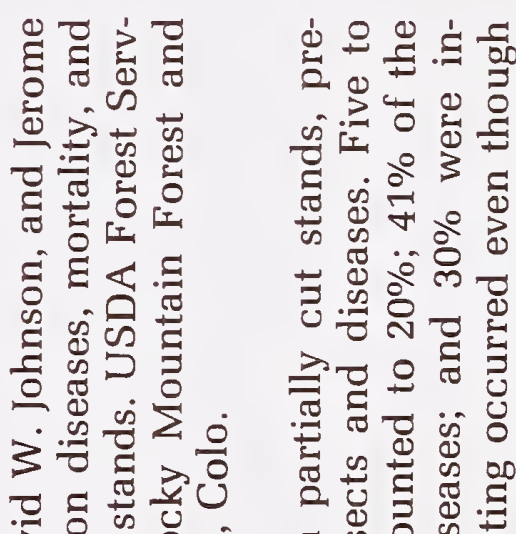
జ

क.

ป ป

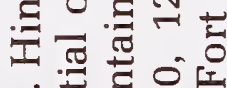

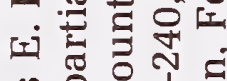

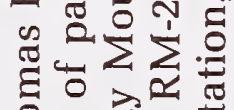
\& क्षेक क Е

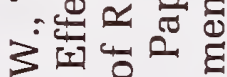
\& ำ 늉 ฮี 즈류

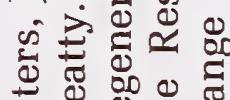
了.

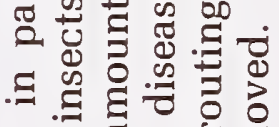

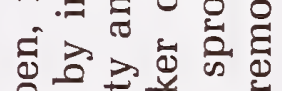
की

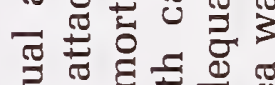

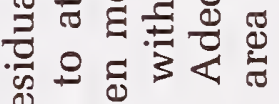

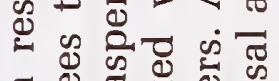
ฮี ๘

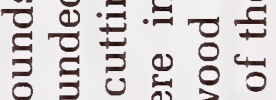
उंड

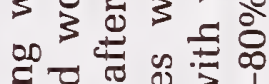

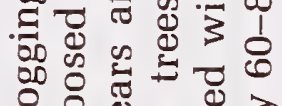

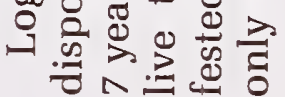

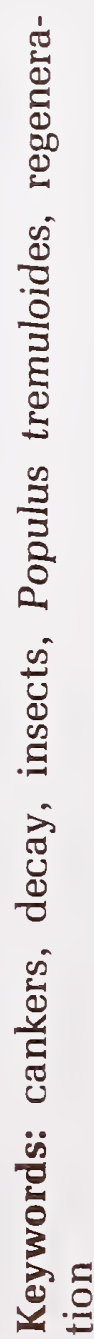




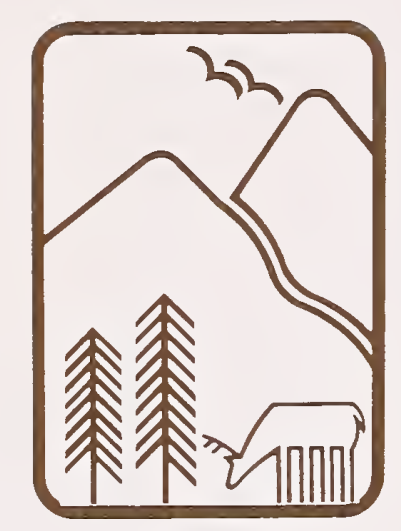

Rocky

Mountains

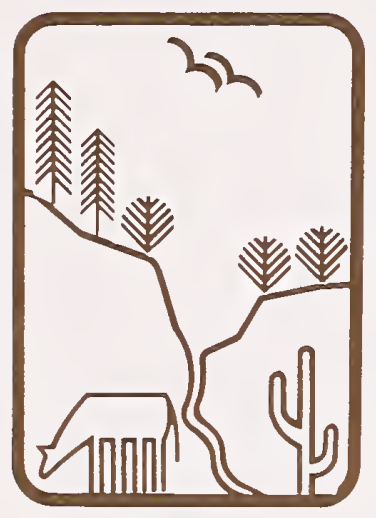

Southwest

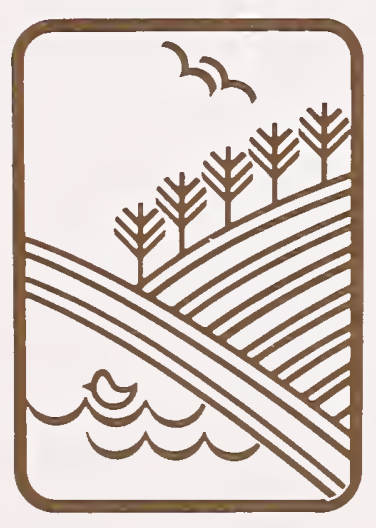

Great

Plains
U.S. Department of Agriculture

Forest Service

\section{Rocky Mountain Forest and Range Experiment Station}

The Rocky Mountain Station is one of eight regional experiment stations, plus the Forest Products Laboratory and the Washington Office Staff, that make up the Forest Service research organization.

\section{RESEARCH FOCUS}

Research programs at the Rocky Mountain Station are coordinated with area universities and with other institutions. Many studies are conducted on a cooperative basis to accelerate solutions to problems involving range, water, wildlife and fish habitat, human and community development, timber, recreation, protection, and multiresource evaluation.

\section{RESEARCH LOCATIONS}

Research Work Units of the Rocky Mountain Station are operated in cooperation with universities in the following cities:

Albuquerque, New Mexico

Bottineau, North Dakota

Flagstaff, Arizona

Fort Collins, Colorado*

Laramie, Wyoming

Lincoln, Nebraska

Lubbock, Texas

Rapid City, South Dakota

Tempe, Arizona

"Station Headquarters: 240 W. Prospect St., Fort Collins, CO 80526 